Vietnam Academy of Science and Technology
(VAST)

\title{
Late Pleistocene-Holocene sequence stratigraphy of the subaqueous Red River delta and the adjacent shelf
}

Nguyen Trung Thanh1, Paul Jing Liu², Mai Duc Dong1, Dang Hoai Nhon, Do Huy Cuong1, Bui Viet Dung 3 , Phung Van Phach ${ }^{1}$, Tran Duc Thanh4, Duong Quoc Hung', Ngo Thanh Nga $^{5}$

${ }^{1}$ Institute of Marine Geology and Geophysics (VAST), Hanoi, Vietnam

${ }^{2}$ Department of Marine, Earth, and Atmospheric Sciences, North Carolina State University, Raleigh, NC 27695, USA

${ }^{3}$ Vietnam Petroleum Institute, 173-Trung Kinh, Hanoi, Vietnam

${ }^{4}$ Institute of Marine Environment and Resources (VAST), Hai Phong, Vietnam

${ }^{5}$ Institute of Geography (VAST), Hanoi, Vietnam

Received 22 February 2018; Received in revised form 02 May 2018; Accepted 05 June 2018

\begin{abstract}
The model of Late Pleistocene-Holocene sequence stratigraphy of the subaqueous Red River delta and the adjacent shelf is proposed by interpretation of high resolution seismic documents and comparison with previous research results on Holocene sedimentary evolution on the delta plain. Four units (U1, U2, U3, and U4) and four sequence stratigraphic surfaces (SB1, TS, TRS and MFS) were determined. The formation of these units and surfaces is related to the global sea-level change in Late Pleistocene-Holocene. SB1, defined as the sequence boundary, was generated by subaerial processes during the Late Pleistocene regression and could be remolded partially or significantly by transgressive ravinement processes subsequently. The basal unit U1 (fluvial formations) within incised valleys is arranged into the lowstand systems tract (LST) formed in the early slow sea-level rise 19-14.5 cal.kyr BP, the U2 unit is arranged into the early transgressive systems tract (E-TST) deposited mainly within incised-valleys under the tideinfluenced river to estuarine conditions in the rapid sea-level rise $14.5-9$ cal.kyr BP, the U3 unit is arranged into the late transgressive systems tract (L-TST) deposited widely on the continental shelf in the fully marine condition during the late sea-level rise $~ 9-7$ cal.kyr BP, and the U4 unit represents for the highstand systems tract (HST) with clinoform structure surrounding the modern delta coast, extending to the water depth of 25-30 m, developed by sediments from the Red River system in 3-0 cal.kyr BP.
\end{abstract}

Keywords: Sequence stratigraphy; Systems tracts; Red River delta; Sedimentary evolution; Sedimentary facies.

(C2018 Vietnam Academy of Science and Technology

\section{Introduction}

Application of sequence stratigraphy has been used for numerous continental shelves to increase deep insights to the history of late Pleistocene-Holocene sedimentary evolution

*Corresponding author, Email: ntthanh@imgg.vast.vn in relation to the global sea-level change. A significant amount of high resolution seismic data collected on the modern continental shelves facilitates for applying the sequence stratigraphy theories (Boyd et al., 1992; Saito et al., 1998; Hanebuth et al., 2004; Dung et al., 2013; Yoo et al., 2014; Thanh, 2017 etc.). 
Numerous classifications of sedimentary system tracts and sequence boundaries have been proposed by other authors based on various case studies (Posamentier et al., 1998; Van Wagoner et al., 1988; Embry and Johannessen, 1992 and Posamentier and Allen, 1999; Hunt and Tucker, 1992, 1995 etc.). Some recent researches on sequence stratigraphy aim to the standardization of sequence stratigraphy concepts or definitions (Catuneanu et al., 2002, 2006, 2009, and 2011). As a result, a complete sequence includes four systems tracts: lowstand systems tract (LST), transgressive systems tract (TST), highstand systems tract (HST), and falling stage systems tract (FSST) (Catuneanu et al., 2002, 2006, 2009, and 2011).

In the Red River Delta, a variety of research results on the Holocene delta evolution based on around 16 boreholes (Tanabe et al., 2003a,b; Hori et al., 2004; Tanabe et al., 2006; Funabiki et al., 2007; Lieu, 2006). In general, the sedimentary evolution of the Red River Delta has experienced three major stages: fluvial stage, estuary stage and delta stage (Lam, 2003; Tanabe et al., 2003b,c; Hori et al., 2004; Tanabe et al., 2006; Lieu, 2006; Funabiki et al., 2007). A number of sedimentary environments were reconstructed by investigating the sediment cores of these boreholes. Application of sequence stratigraphy on the modern delta plain in late PleistoceneHolocene was carried out and the stratum was divided into three system tracts LST, TST and HST (Tanabe et al., 2006).

However, the understanding on the Red River subaqueous delta and the adjacent shelf is still sparse. Some previous researchers on the Red River subaqueous delta consist of sedimentation and sediment dynamics (Bergh et al., 2007; Duc et al., 2007; Ross, 2011). Therefore, unraveling the sedimentary evolution of the Red River subaqueous delta needs to be conducted in more detail. These obtained research results will satisfy require- ments for coastal protection and forecast of the Red River delta in the present sea-level rise and human impacts from the upstream to the lowland delta plain. The available research results on delta plain would be able to assist interpreting seismic facies on the seismic profiles. In this research, we focused on determining some major sedimentary environments and using sequence stratigraphy theory to develop a simplified concept sequence stratigraphy model for the study area.

\section{Background information}

\subsection{Geography}

The Red River originates from the mountainous range of Yunnan Province, China at an elevation above $2000 \mathrm{~m}$ and drains an area of $160 \times 10^{3} \mathrm{~km}^{2}$ (Milliman and Syvitski, 1992). The Red River flows through two countries as China and Vietnam before discharges into the Gulf of Tonkin in the East Sea. The total sediment discharge is $~ 100-130$ million ton/yr and the water discharge is 120 $\mathrm{km}^{3} / \mathrm{yr}$ (Milliman and Mead, 1983; Milliman and Syvitski, 1992). The water mean discharge is $3300 \mathrm{~m}^{3} / \mathrm{s}$, which was estimated in recent years (Luu et al., 2010). Approximately $90 \%$ of the sediment discharge occurs during the summer monsoon season (Mathers et al., 1996; Mathers and Zalasiewicz, 1999). In the Red River delta plain, the river system subdivides into two major distributaries in the vicinity of Hanoi, the Red River to the southwest and the Thai Binh River to the northeast (Figure 1). The Thai Binh River transports $20 \%$ of the total water discharge of the delta river system (General Department of Land Administration, 1996). The sediment discharge of the Red river has built one of the largest deltas in the world during the Holocene. The youngest geomorphological unit of the Red River delta as known the subaqueous delta is located below the present sea level and reaches the water depth of 25-30 m 
(Figure 1). The study area includes the subaqueous Red river delta and adjacent shelf ex- tending the water depth of $\sim 40 \mathrm{~m}$ and southwards to the latitude $18.5^{\circ} \mathrm{N}$ (Figure 1).

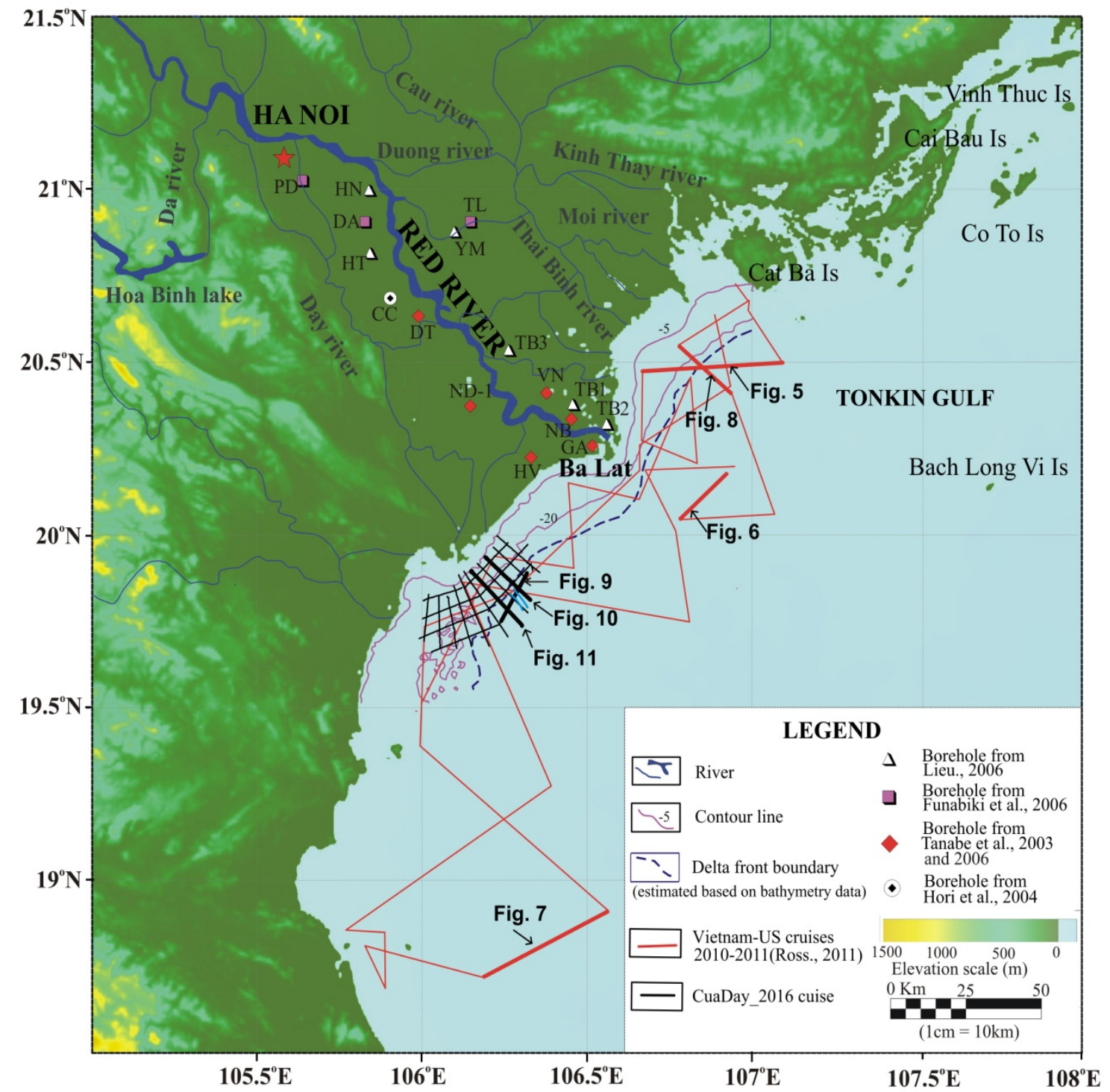

Figure 1. Study area (available boreholes on the Red River delta plain and recorded seismic profiles)

\subsection{Oceanography}

The tide is characterized by semi-diurnal regime with an average range $\sim 2.0-2.6 \mathrm{~m}$ (Coleman and Wright, 1975). The maximum tide ranges $\sim 3.2-4.0 \mathrm{~m}$ along the Red River delta coast (Mathers et al., 1996; Mathers and Zalasiewicz, 1999; Thanh and Huy, 2000). In the summer monsoon season, the high river discharge restricts tidal influence into the Red River distributaries. The tidal effect is visible in all the major distributaries almost as far inland as Hanoi in the winter monsoon season due to the low river discharge (Mathers et al., 1996; Mathers and Zalasiewicz, 1999). 
Along the delta coast, mean and maximum wave heights are respectively $\sim 0.88$ and $5.0 \mathrm{~m}$ (Thanh and Huy, 2000). The strong southwest wind during the summer monsoon tends to produce north, northwest-directed waves in the Gulf of Tonkin. Throughout most of the rest of the year, the wind blows from the east, north-east and produces south, south-westdirected waves (Mathers et al., 1996; Mathers and Zalasiewicz., 1999). In accordance with the study of Mathers et al. (1996), the Red River deltaic coast is considered a mixed energy coast (tide-wave dominated coast).

\subsection{Holocene sedimentary evolution on the Red River delta plain}

The geographical area of the Red River delta and the adjacent continental shelf had been exposed to subaerial processes during the last glacial maximum stage (LGM) 23-19 cal.kyr BP. The paleo-river systems flowed through the area of interest and generated incised valley systems in this period. A large incised valley on the delta plain was recognized through the borehole ND-1, located at southwestward of the Red River delta. After the last glacial maximum, the sea-level rose approximately from $-120 \mathrm{~m}$ to $-90 \mathrm{~m}$ in the stage 19-14.5 cal.kyr BP and was able to cause the early infilling of fluvial sediments within incised-valleys. The lithology of fluvial sediments in the borehole ND-1 demonstrated pebbly sand (Facies 1.1) (Figure 2) (Tanabe et al., 2006). Then the sea level continued to rise from $-90 \mathrm{~m}$ to $-7 \mathrm{~m}$ in the stage $\sim 14.5-8$ cal.kyr BP that caused the flood of the entire continental shelf and established the area of the Red River delta plain becoming a large estuary. A variety of sedimentary facies formed in the estuarine condition include: tideinfluenced channel-fill to coastal marsh (facies 2.1), lagoon muddy sediments (facies 2.2), flood tidal delta (facies 2.3), tidal flat and salt marsh (facies 2.4), sub to intertidal flat (facies 2.5) and estuarine front sediments (facies 2.6) (Figure 2) (Tanabe et al., 2003a,b; Hori et al., 2004; Tanabe et al., 2006; Funabiki et al., 2007; Lieu, 2006). The Red River delta initiated since $\sim 8.1$ cal.kyr BP (Tanabe et al., 2006) corresponding to the decelerating rise of sea-level (Hori et al., 2004). Subsequently, the sea level gradually declined $\sim 3$ $\mathrm{m}$ till the present sea-level since the highstand sea level in 6-4 cal.kyr BP. This sea-level fall is one of the factors increasing the speed of the delta progradation seawards. A variety of sedimentary deltaic facies were found including: tide-influenced channel-fill (facies 3.1), shelf to prodelta (facies 3.2), delta front slope (facies 3.3), delta front platform (facies 3.4), sub-tidal flat (facies 3.5), tidal flat (facies 3.6), mangrove swamp/salt marsh (facies 3.7), tide-influenced channel-fill (facies 3.8), natural levee (facies 3.9), abandoned channelfill (facies 3.10), delta flood plain (facies 3.11) (Tanabe et al.,2006) (Figure 2). The available ${ }^{14} \mathrm{C}$ dating data of sediment cores on the delta plain indicates that the fluvial facies at base of incised valleys were formed before 14.5 cal.kyr BP, the coastal-estuary facies were formed predominately 11-9 cal.kyr BP, and then the delta facies were formed $\sim 8.0-0$ cal.kyr BP (Tanabe et al., 2003b,c; Hori et al., 2004; Tanabe et al., 2006; Lieu, 2006; Funabiki et al., 2007). The sequence stratigraphy approach was also used for investigating the delta plain based on drilling core data (Tanabe et al., 2016). Three sedimentary systems tracts divided include: lowstand systems tract (LST), transgressive systems tract (TST), and highstand systems tract (HST) (Figure 2) (Tanabe et al., 2016). 

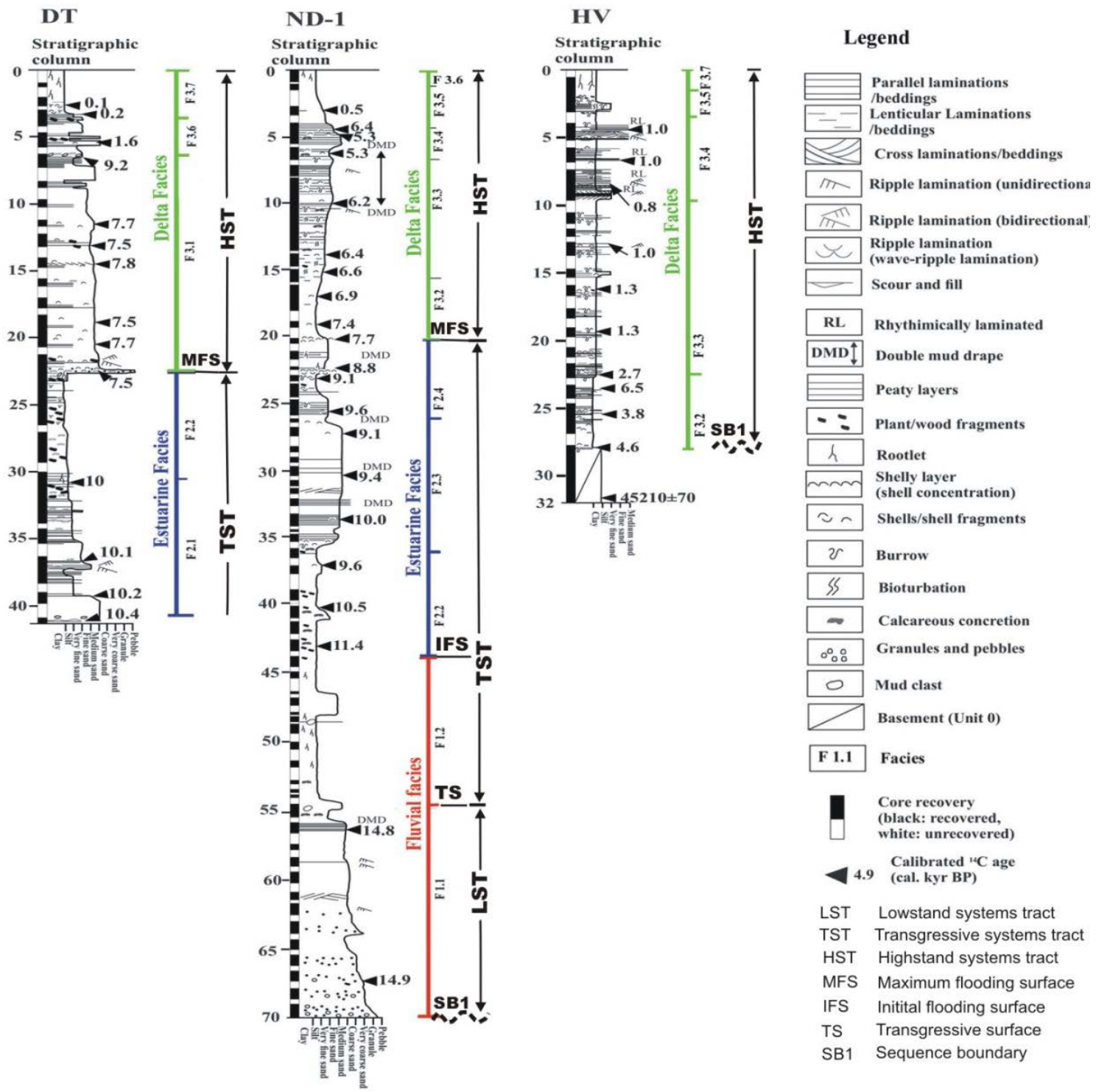

Figure 2. Sedimentary facies and systems tracts in sediment cores DT, ND-1 and HV (Tanabe et al., 2006)

\section{Methodology and documents}

\subsection{Sequences stratigraphy methodology}

Sequence stratigraphy is used as a methodology providing a framework for the elements of any depositional setting, facilitating paleogeographical reconstruction and predicting lithofacies away from control points (Catuneanu et al., 2011). A complete sequence includes four systems tracts: falling-stage systems tract (FSST), lowstand systems tract (LST), transgressive systems tract (TST) and highstand systems tract (HST) (eg., Hunt and Tucker, 1992, 1995; Helland-Hansen and Gjelberg, 1994; Catuneanu et al., 2009, 2011). Each systems tract is separated with the underline systems tract and overlying systems tract by the major bounding surfaces such as SB (sequence boundary), TS (transgressive surface), TRS (transgressive revinement surface) and MFS (maximum flooding surface) (eg., Catuneanu et al., 2009, 2011). The transgressive surface was named alternatively such as 'initial transgressive surface' ITS 
(Nummedal et al., 1993) and had been established in the early period of sea-level rise after the lowstand sea-level. The transgressive ravinement surface (TRS) was named alternatively such as RS in a number of researches (Dung et al., 2013; Yoo et al., 2014 etc.). The transgressive ravinement surface (TRS) had been generated by strong marine erosion of waves and littoral currents in the coast and shallow-water settings. The maximum flooding surface (MFS) has been generated by sediment starvation stage on the continental shelf due to the farthest invasion of sea landward.

Each sequence is corresponding to a sedimentary cycle bounded by sequence boundaries (SB). Generally, a complete sequence includes four systems tracts (LST, TST, HST, FSST) (Figure 3A). Sedimentary cycles are arranged into the first, second, third, fourth, and fifth orders (e.g., Catuneanu et al., 2011). These orders correspond to the geological time scales from tens of millions of years to tens of thousands of years. The concepts of the systems tracts are defined as follow:

(i) The falling stage systems tract (FSST) was formed entirely during the stage of relative sea-level fall (forced regression).

(ii) The lowstand systems tract (LST) was formed during the earliest stage of relative sea-level rise at the lower rate than the sedimentation rate (normal regression).

(iii) The transgressive systems tract (TST) was formed during the stage of relative sealevel rise at the higher rate than the sedimentation rate.

(iv) The highstand systems tract (HST) was formed during the latest stage of relative sealevel rise at lower rate than the sedimentation rate.

In this study, we focus on investigating the development of sequence stratigraphy on the subaqueous Red River delta and the adjacent shelf since LGM ( 23-19 cal.kyr BP) to the present. In this period, the sea-level rose slowly in the early stage of $\sim 19-14.5$ cal.kyr BP, at the higher speed in the stage $\sim 14.5-8 \mathrm{cal} . \mathrm{kyr}$ $\mathrm{BP}$, decelerating rise of sea-level in the stage of 8-6 cal.kyr BP (Hanebuth et al., 2011; Tanabe et al., 2006). Then the sea level has declined $\sim 2-3 \mathrm{~m}$ to the present sea-level since 4-6 cal.ky BP (Lam and Boyd, 2000; Tanabe et al., 2006). Three systems tracts were divided relatively based on the deglacial sea-level change since LGM and classification of systems tracts on the delta plain. The lowstand systems tract was generated in $\sim 19-14.5$ cal.kyr BP, the transgressive systems tract was generated in 14.5-7.0 cal.kyr BP, and the highstand systems tract was generated $\sim 7-0$ cal.kyr BP. (Figure 3B).

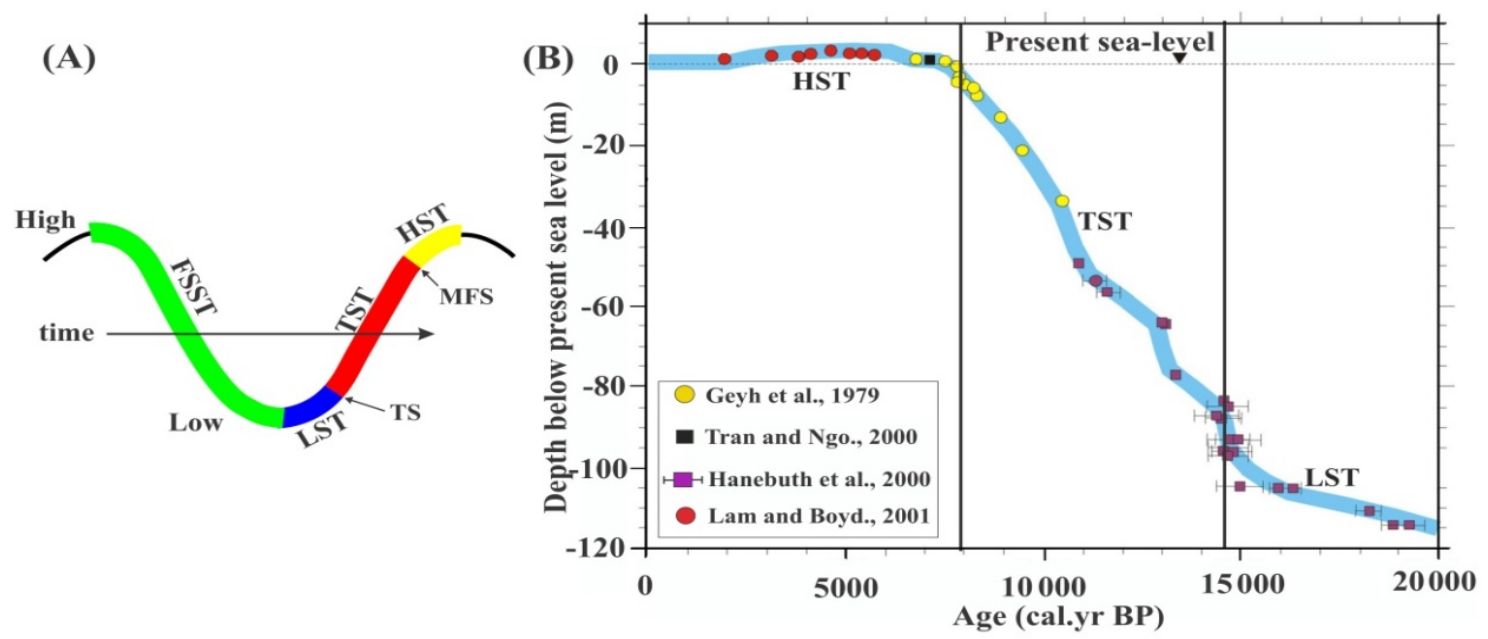

Figure 3. (A) Systems tracts (FSST, LST, TST, HST) and surfaces (TS and MFS) (Hunt and Tucker, 1992);

(B) The sea-level curve for the study area (Tanabe et al., 2006) and classification of systems tracts since LGM (LST, TST and HST) 


\subsection{Seismic interpretation and facies analysis}

A number of seismic profiles were referred from some previous documents such as RR102, RR2-08, RR2-19 and RR2-22 (Ross, 2011) (Figure 1). This data collected in 2010 and 2011 with about $1100 \mathrm{~km}$ in the cooperation between North Carolina State University, United States and Institute of Marine Environment and Resources, Vietnam, by using EdgeTech X-Star 0512i Chirp Sonar SubBottom profiler with a frequency range of 0.5$12 \mathrm{kHz}$ and the vertical resolution of data is 4$50 \mathrm{~cm}$.

The high-resolution seismic reflection data were collected in 2016 with approximately $200 \mathrm{~km}$ by using a Sparker system, with the pulse rate of 1 second, energy max 2800J, trace length of 150-250 ms and a frequency range of 200-1000 Hz. This data was recorded around the Day river mouth, which is located southwestward over $50 \mathrm{~km}$ from the Balat river mouth (Figure 1).

Seismic data was interpreted on the basis of the sequence stratigraphic concept proposed by Mitchum and Vail (1977) and further refined by other authors. The seismic units were distinguished by their reflection continuity, amplitude, frequency and geometry of seismic facies. For example, a relative classification of seismic facies and related depositional environments were adapted by Badley (1985), Vail (1987) and Veeken (2006) (Figure 4).
CONTINUITY

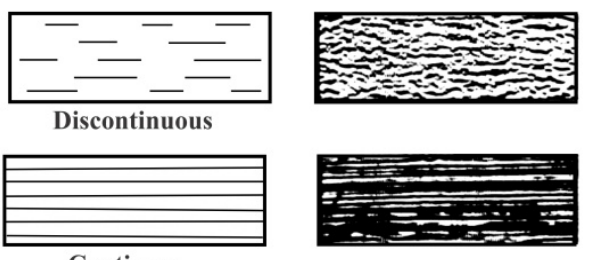

Continuos

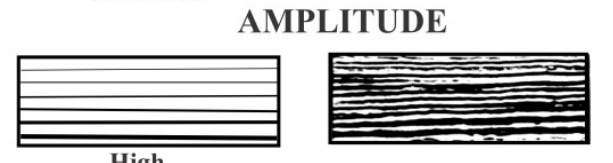

High

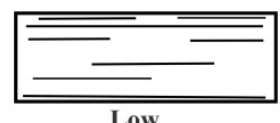

FREQUENCY/SPACING

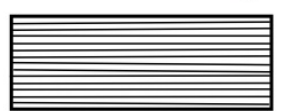

High

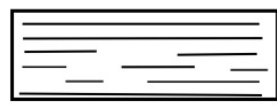

Low
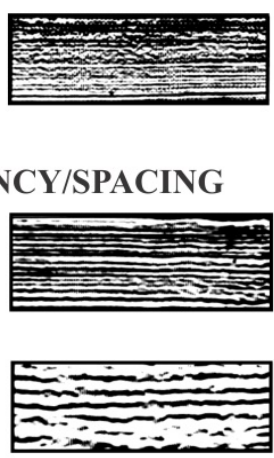

CONFIGURATION

INTERPRETATION

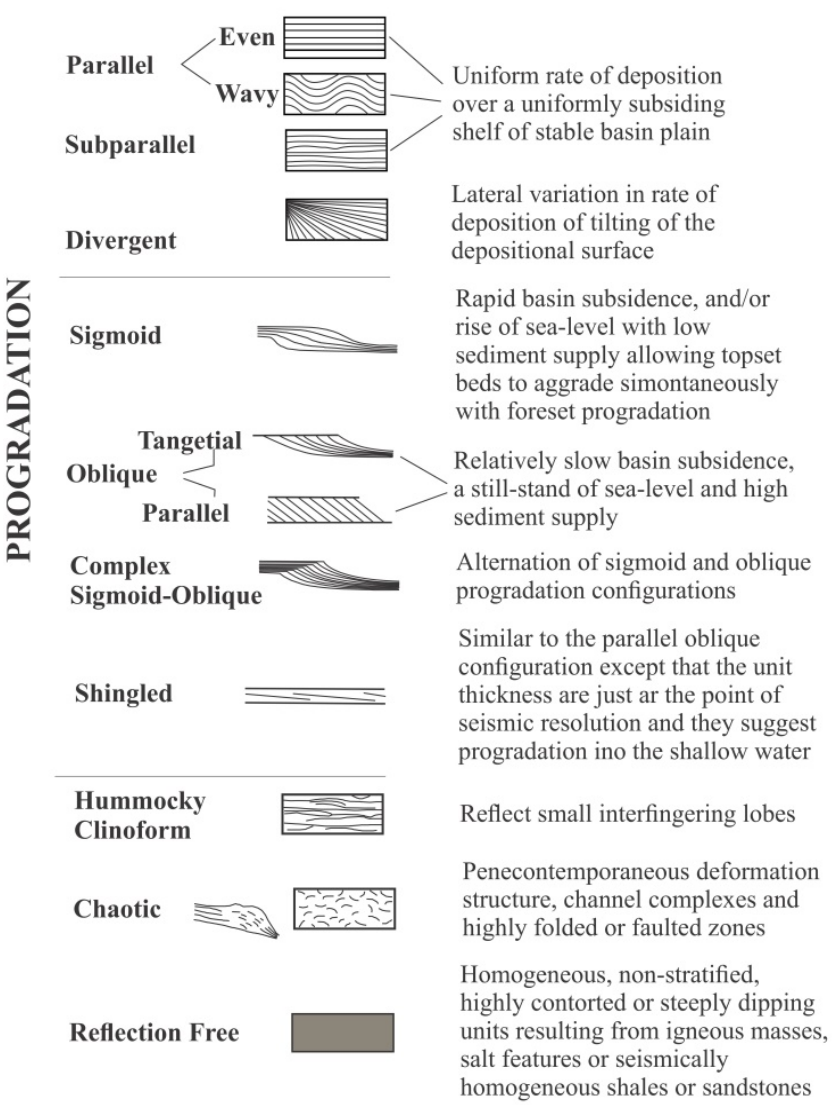

Figure 4. Relative classification of seismic facies and related depositional environments adapted by Badley (1985), Vail (1987) and Veeken (2006) 
Nguyen Trung Thanh, et al./Vietnam Journal of Earth Sciences 40 (2018)

\section{Results and Discussion}

\subsection{Research results}

In general, four seismic units and four bounding major surfaces were identified on the seismic profiles. The seismic units are named by increasing number in order of decreasing age:

Major bounding surfaces:

(i) SB1 is marked by highly continuous and strong amplitude reflections in the recorded seismic document. It could be observed on the seismic profiles (Figure 5-11).

(ii) TS can be traced in some incisedvalleys, where it is characterized by weak amplitude and is almost merged with the surface
SB1 towards the edges of some incisedvalleys (Figure 5-7).

(iii) TRS mainly traced in some incisedvalleys, where it is characterized by moderate amplitude, and tends to merge with TS and SB1 towards the edges of some incised valleys (Figure 5, 6, 8 and 9).

(iv) MFS is marked by medium to low amplitude and relatively continuous reflectors. MFS was recorded in the inner shelf around the modern Red River Delta (0-25 m in water depth), which generally forms the boundary between the lower sheet-like transparent reflector unit and the overlying seaward clinoform unit (Figure 5, 8, 10 and 11).
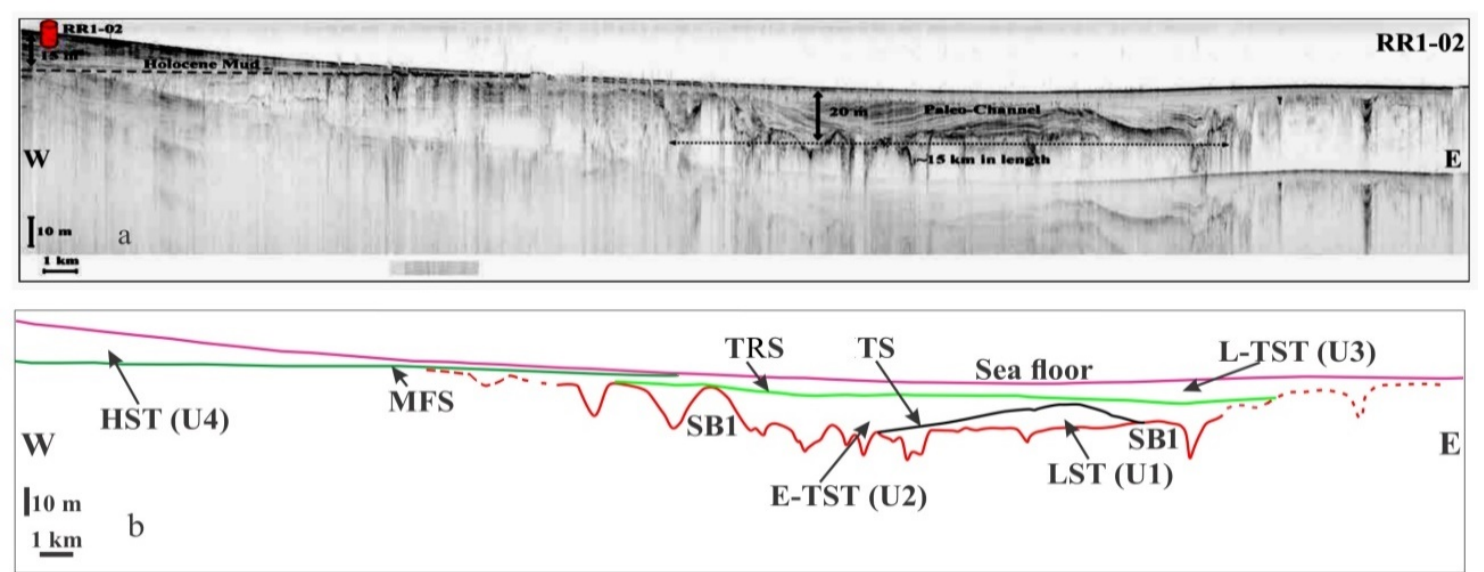

Figure 5. (a) Seismic profile RR1-02 (Ross, 2011), (b) sequence stratigraphic interpretation
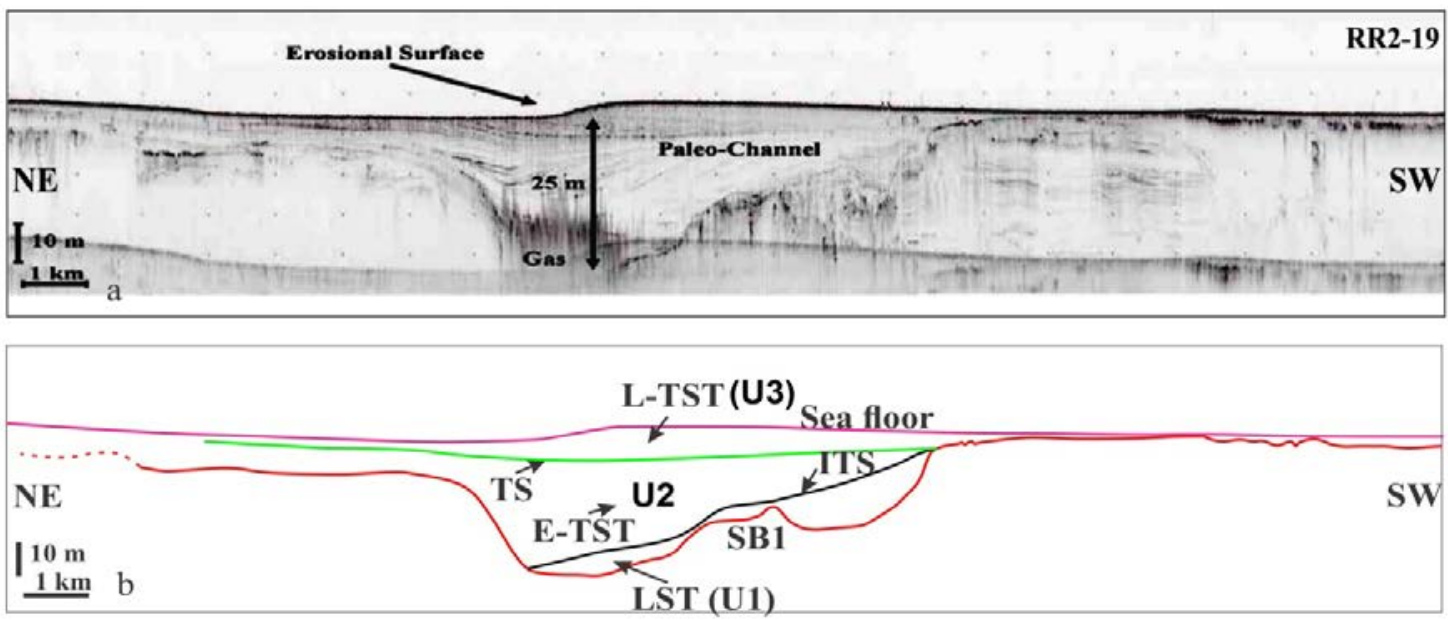

Figure 6. (a) Seismic profile RR2-19 (Ross, 2011), (b) sequence stratigraphic interpretation 
Seismic units:

U1 is characterized by steeply inclining reflectors locating on one side within some incised valleys (indicating the development of fluvial bar) (Figure 7) or strong acoustic reflection fields that are recorded at the base of the incised-valley system (Figure 5 and 6). Its deposits occupy in the basal part of the channels. It is represented by the medium amplitude and low to medium continuity reflectors. The maximum thickness of this unit reaches $\sim 10 \mathrm{~m}$.

$\mathrm{U} 2$ is recorded mainly within the incisedvalley system and represented by low to medium amplitude and medium continuity re- flectors. The seismic fields indicate the sedimentary structure that conforms approximately to the channel shape with upward concavity layers in the lower portion, to asymmetrically steeply inclined layers, horizontal layers upwards. It overlies on unit U1 or the surface SB1 (Figure 5-8) and its maximum thickness reaches $\sim 20 \mathrm{~m}$.

U3 is recorded widely on the entire continental shelf and represented by weak horizontal layers to the transparent layer with the thickness often less than $4 \mathrm{~m}$. It distributes widely on the continental shelf and is overlain by unit U4 in the subaqueous delta area (Figure 5, 6, 8 and 9).

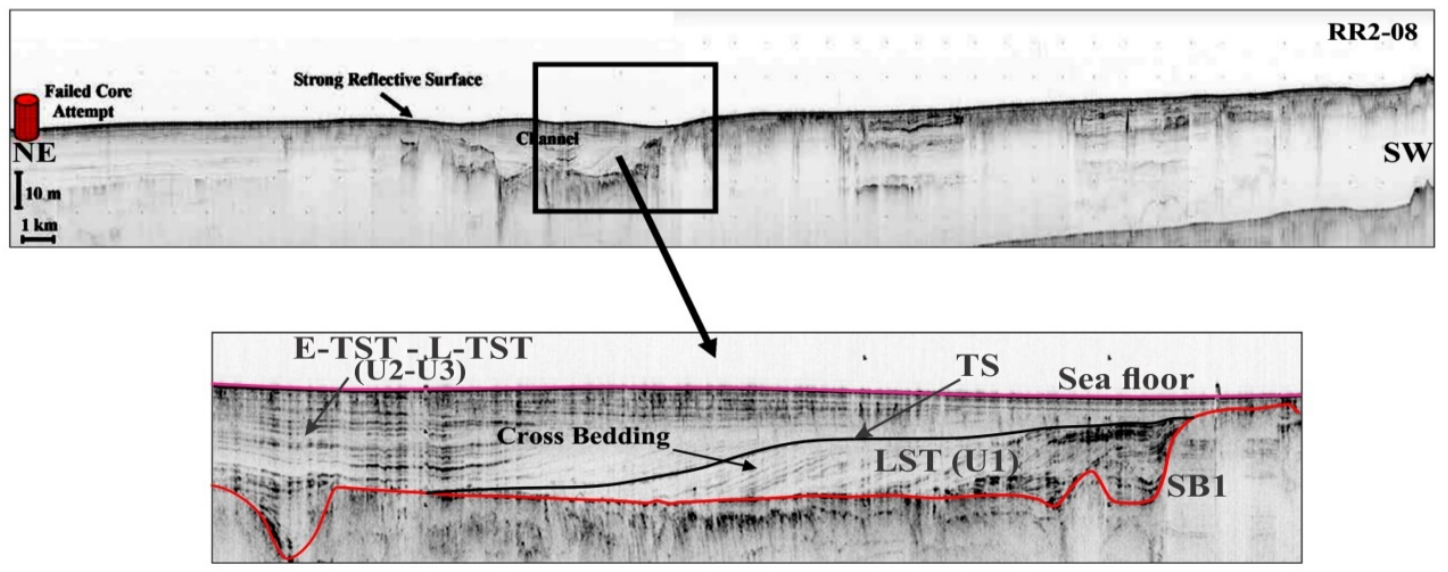

Figure 7. (a) Seismic profile RR2-08 (Ross, 2011), (b) sequence stratigraphic interpretation
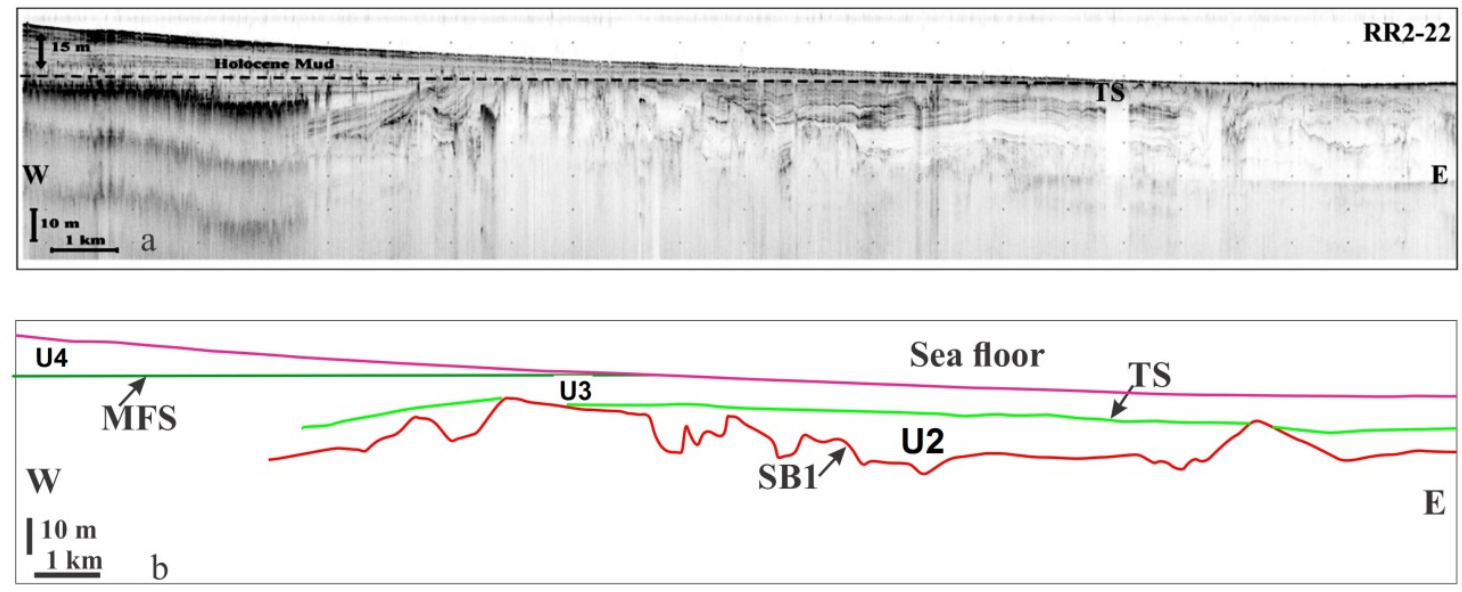

Figure 8. (a) Seismic profile RR2-22 (Ross, 2011), (b) sequence stratigraphic interpretation 
Nguyen Trung Thanh, et al./Vietnam Journal of Earth Sciences 40 (2018)
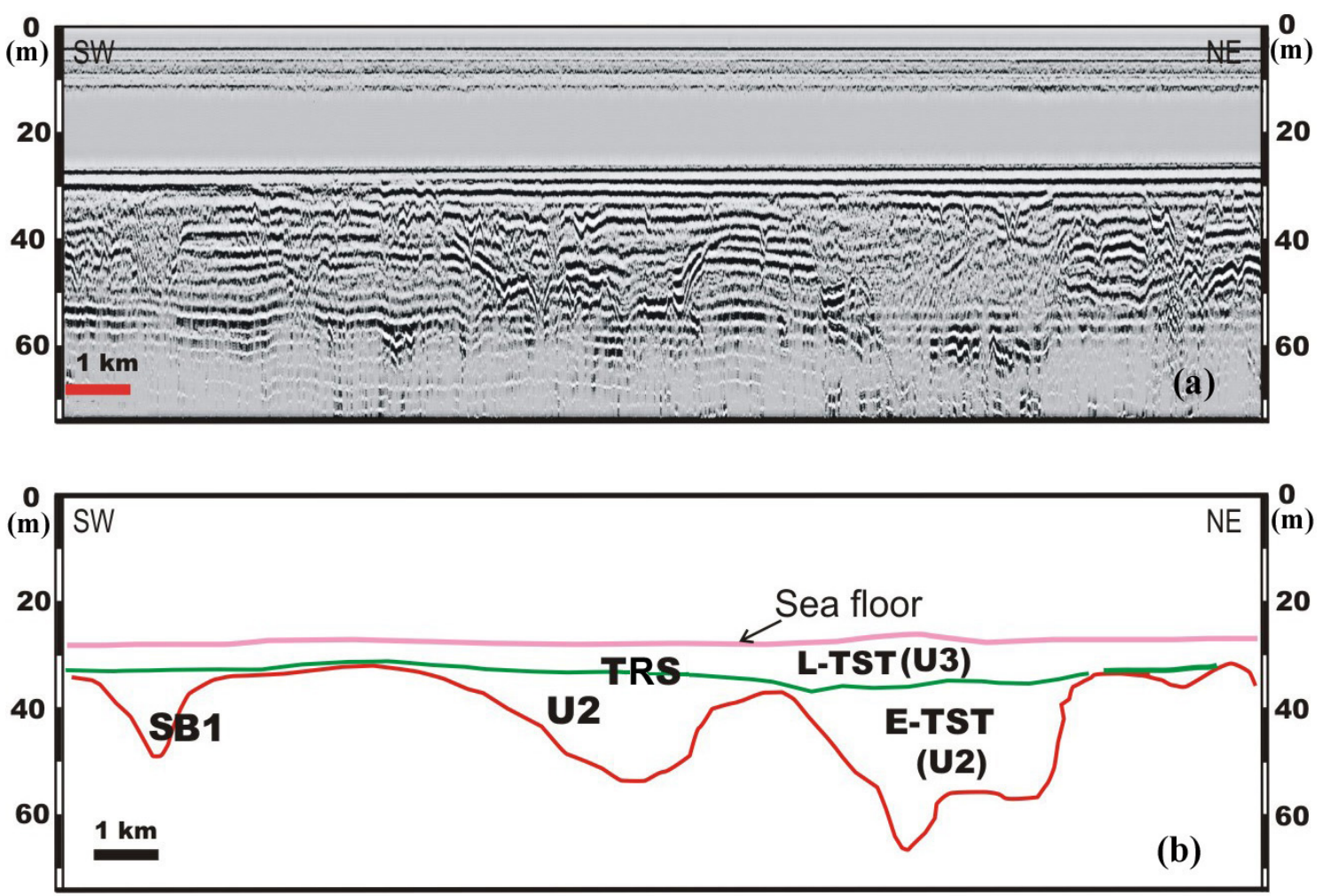

Figure 9. (a) Seismic profile CuaDay-15, (b) sequence stratigraphic interpretation
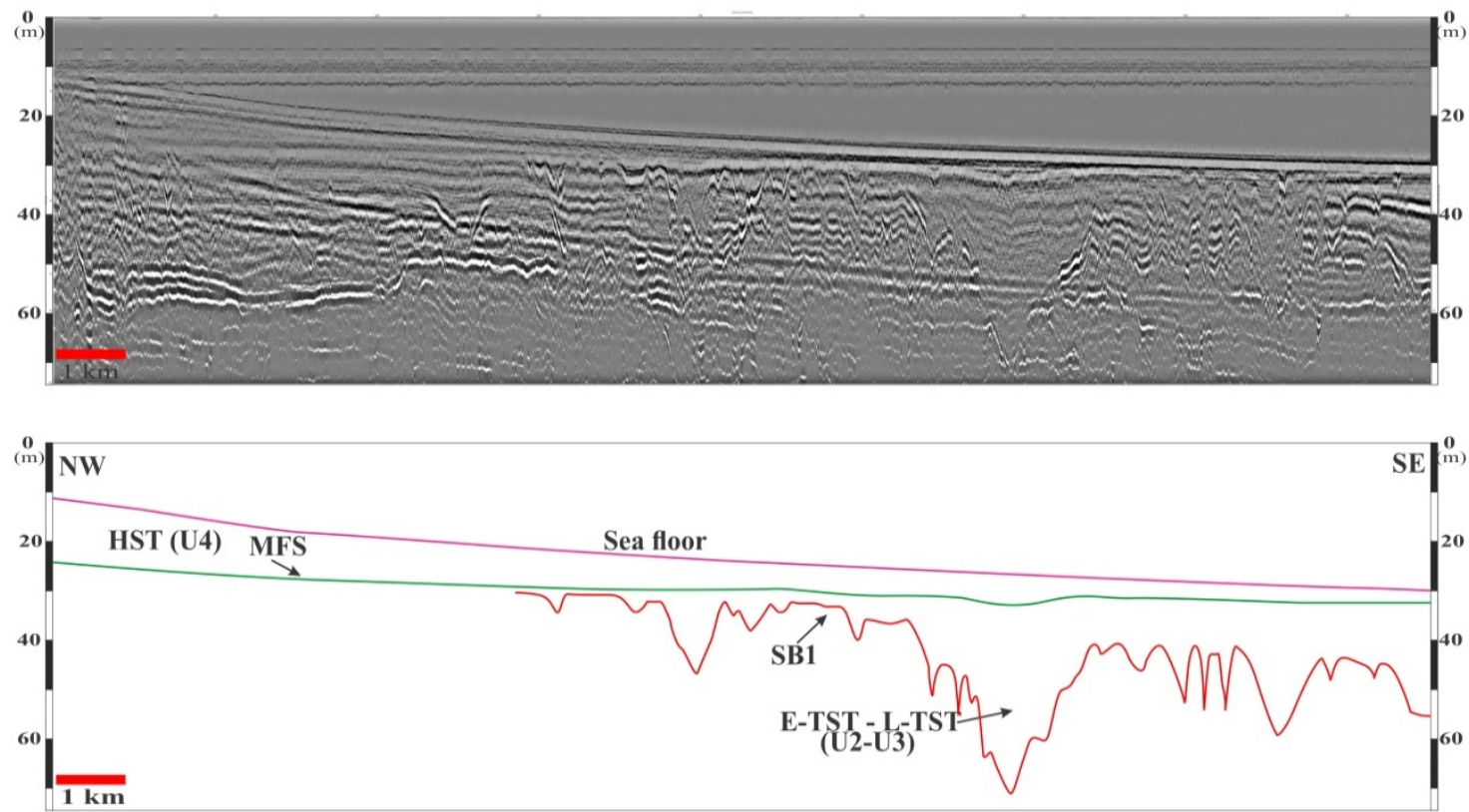

Figure 10. (a) Seismic profile CuaDay_03, (b) sequence stratigraphic interpretation 

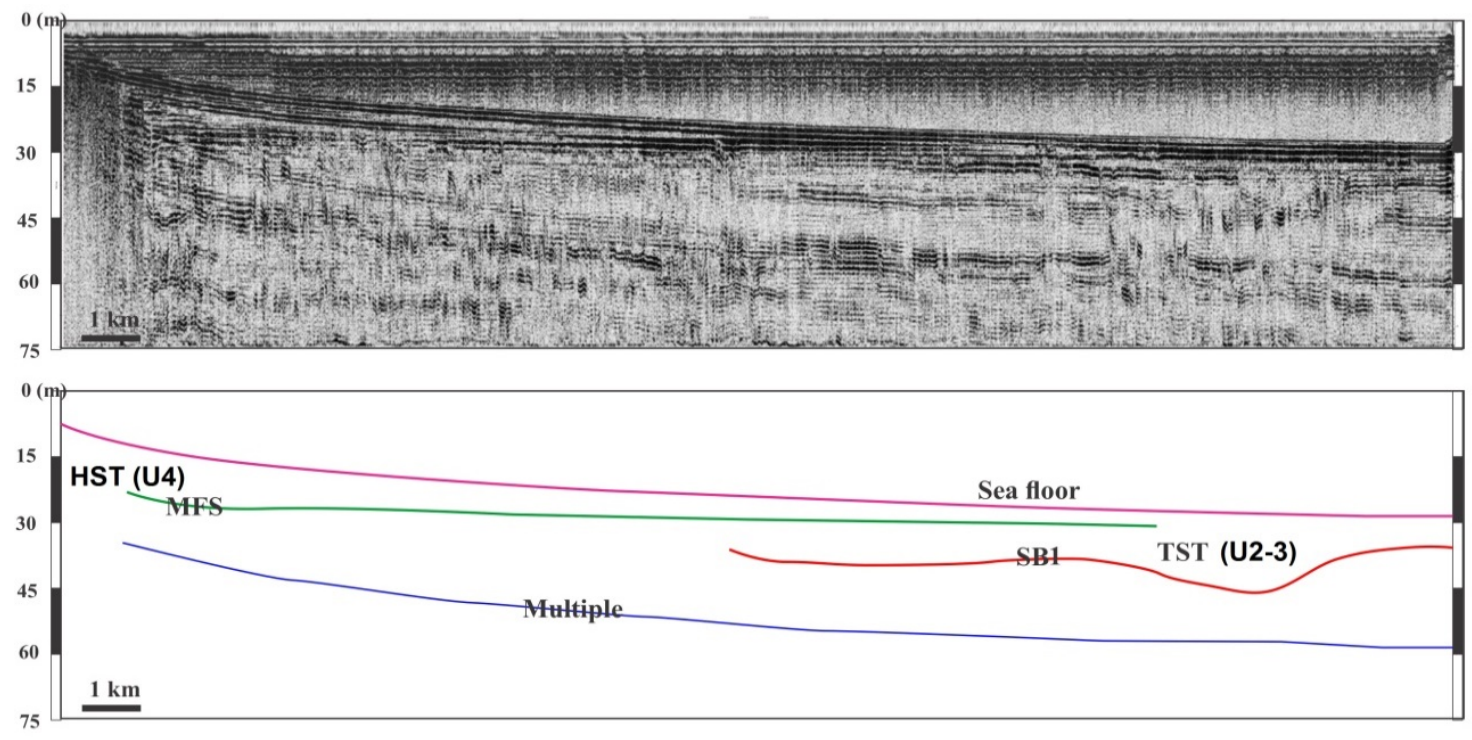

Figure 11. (a) Seismic profile CuaDay_05, (b) sequence stratigraphic interpretation

U4 is the uppermost portion and well recorded in the subaqueous Red River Delta (0$25 \mathrm{~m}$ in water depth) and surrounds the modern delta coast (Figure 1), showing dipping reflectors. It forms a tangential downlap structure to the MFS surface. The thickness of U4 ranges in $\sim 15-20 \mathrm{~m}$ estimated at the topset portion and tends to be thinning seaward (Figure 5, 8, 10 and 11).

\subsection{Discussions}

The sea-level curve for the East Sea (also known as the South China Sea in the international name) since LGM can be divided into three parts as mentioned (Figure 3B). In some previous studies, the paleo-sea level at LGM was suggested to be located at $\sim 120-125 \mathrm{~m}$ below the present sea-level (Hanebuth et al., 2000, 2004, 2011; Tanabe et al., 2006). The paleo-shoreline in the East Sea during that time was situated near the shelf margin at the present water depth of $\sim 120 \mathrm{~m}$. The Vietnam continental shelf was gradually exposed to subaerial processes during the Late Pleistocene regression and the stiff tropical soil was formed widely (Thanh, 2017). As a result, an erosional unconformity surface was formed in
LGM. Then the sea-level rise partially or significantly modified this unconformity surface except in incised valleys and depressions. This unconformity surface is defined as the sequences boundary (SB1). The SB1 surface on the shelf in the Gulf of Tonkin could be similar to the SB1 surface determined on the SE Vietnam Shelf and the Sunda Shelf that was defined by Dung et al. (2013), Thanh (2017), and Hanebuth et al. (2011). In the nearshore area, the depth of SB1 is approximately 25-30 m below the present sea-level and it deepens seaward. The paleo-Red River and some other paleo-rivers flowed through the continental shelf during the LGM and generated incised-valleys. The large incised valleys reach $\sim 20-30 \mathrm{~m}$ deep below the seabed and range $\sim 6-10 \mathrm{~km}$ in width (Figure 5-7). The seismic profile RR2-08 is located $>100 \mathrm{~km}$ to the south of the subaqueous delta and quite far from the supplying source of Red River sediments (Figure 1). The seismic characteristics of seabed on the profile RR208 reveals a hard sea bottom (Figure 7) and attempts for coring by the gravity corer failed (Ross, 2011). A large incised-valley, $\sim 6 \mathrm{~km}$ wide in cross section and $\sim 14 \mathrm{~m}$ deep, was observed on this seismic profile (Ross, 2011). 
Based on the seismic profiles (Figure 5, 6 and 8), the major paleo-Red River and some other paleo-rivers were able to flow towards southeast during LGM (Figure 12). The other small incised valleys observed on the profiles CuaDay_03, CuaDay_15-2 located in the southwest of the subaqueous delta represents for local paleo-rivers working in LGM. They are narrow (less than $3 \mathrm{~km}$ wide) and $\sim 15-20$ $\mathrm{m}$ deep in general (Figure 10). The major paleo-rivers were marked on the map based on the data of sediment boreholes on the delta plain and the available seismic profiles recorded on the shelf (Figure 12).

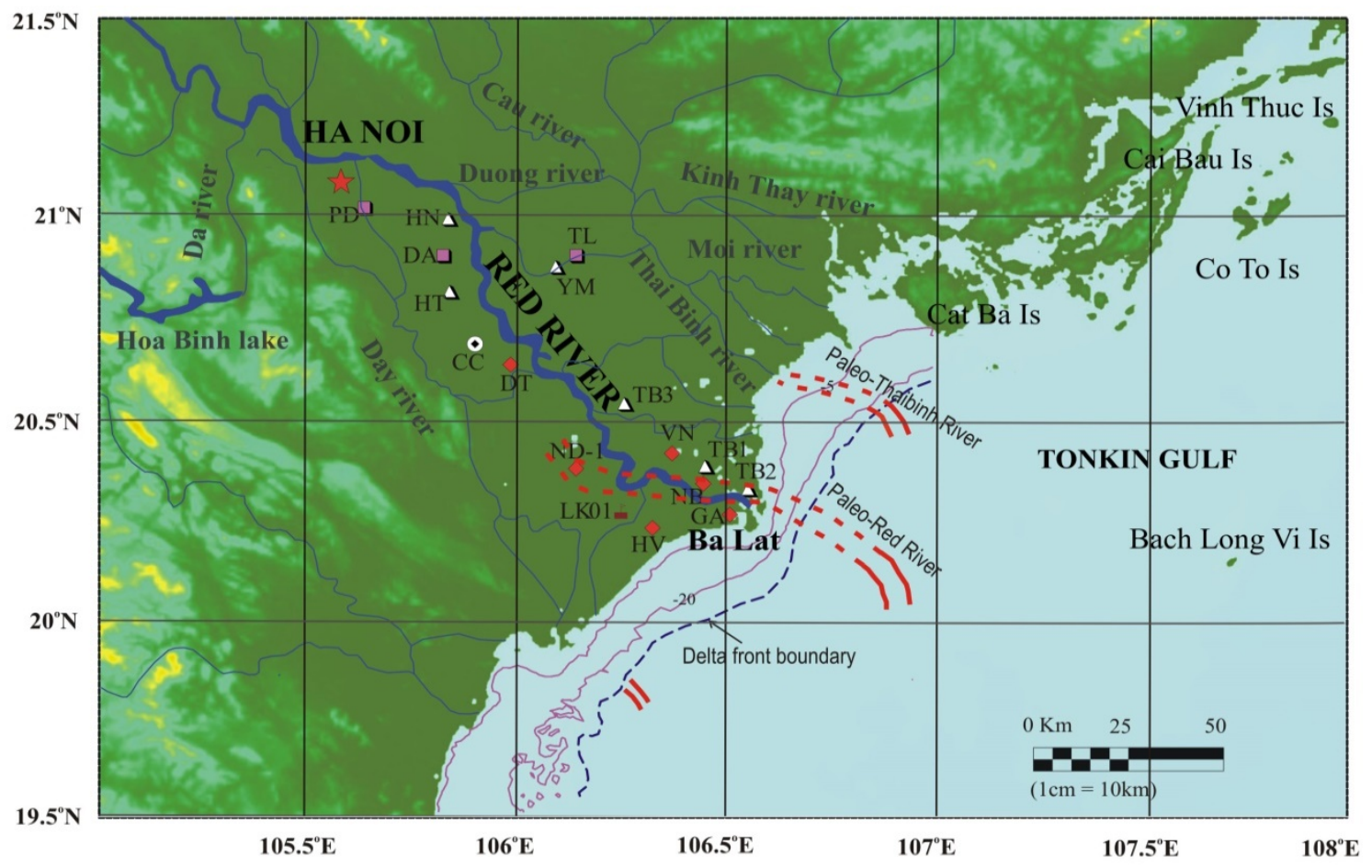

Figure 12. Paleo-river systems on the continental shelf in the last glacial maximum

During the early slow transgression (1914.5 cal.kyr BP), the increase of base level was able to restrict the river incision and caused some lateral shifts of large paleo-river channels or the initial filling of river channels creating fluvial bars on the convex river banks (Figure 7) or formation of pebbly sand occurring at the base of the incised valleys. These sediments (U1) are able to be inferred depositing in the fully fluvial condition in the early sea-level rise stage and arranged into the lowstand systems tract. The U1 unit is determined as the strong seismic field at the base of the incised-valleys (Figure 5 and 6 ) or consists of cross-bedding reflectors that are visi- ble in the seismic profile RR2-08 (Figure 7). In the sediment cores ND-1 (Tanabe et al., 2006) and TB2 (Lieu, 2006) on the delta plain, the fluvial facies corresponding to the U1 seismic unit consists of facies 1.1 in ND-1 and facies 0.3 in the core TB2. This U1 unit is bounded by the basal surface (SB1) and the overlying surface (TS).

During the transgression (14.5-9 cal.kyr $\mathrm{BP})$ with high speed of sea-level rise, a tideinfluenced river to an estuarine environment probably developed. Sediments derived from the paleo-rivers were trapped in the tideinfluenced river to the estuary and formed the sedimentary unit U2. The U2 unit presents 
within incised valleys and its sedimentary structure conforms approximately to the channel shape with upward concavity layers in the lower portion, to asymmetrically steeply inclined layers, horizontal layers upwards (Figure 5 and 6). These structures indicate sediments deposited in the channels under the tide-influenced condition (Reineck and Singh, 1980). The sediment structures usually indicate the intercalation of sand and mud layers (Tjallingii et al. 2010; Thanh, 2017). The sandy sediments deposited in the high-speed flow of water in the ebb tide and flooding tide while the muddy deposits formed in slack tide periods (weak flows). The U2 unit overlies on U1 and normally shows the finning upward of strata due to the sea-level rise. The sedimentary structure of U2 demonstrates the tidal influence on sediment deposition in the river channels in the period $14.5-9$ cal.ky BP. The U2 unit was formed in corresponding to the facies 2.1 of the sediment core ND-01 (Tanabe et al., 2006). This unit is arranged into the early transgressive systems tract (E-TST). Therefore, the TS surface can be defined at the top of the lowstand deposits as a result of the change of depositional conditions from completely river control to tide-influenced river or estuarine environments. The TS surface could be demonstrated in the concept of initial transgressive surface (Nummedal et al., 1993) that was formed in the early sea level rise.

As the transgression continued (9-7 cal.kyr $\mathrm{BP})$, coastal processes including wave and tide actions caused coastal erosion and coastal shallow seabed erosion to form the transgressive ravinement surface (TRS) and sort coarse sediments (U3) overlying this surface. The U3 unit demonstrates the transparent acoustic field or the structure of parallel layers. It generally has a thickness less than $4 \mathrm{~m}$ and could be observed at the upper part of the seismic sections on the adjacent continental shelf. The U3 unit was deposited in the fully marine condition and probably reworked by modern shelf hydrodynamic processes. The transgressive ravinement surface (TRS) tends to merge the surface SB1 towards the banks of incisedvalleys and become one surface that is defined as the sequence boundary (SB1). Therefore, the U3 unit properly overlies on SB1 widely on the continental shelf. In some seismic profiles recorded near the Day river mouth, the seismic facies in some incised-valleys and an adjacent portion is not so clear to identify U2 and U3 separately due to the quality of this data. Therefore, the unit U2-3 was named in these cases (Figure 9 and 10).

In the delta plain, the U3 unit was determined in the drilling cores ND-01, VN, HV and GA as the lower part of facies 3.2 (Tanabe et al., 2006). However, the condition for deposition in landward part in a large estuarine environment is quite different from the open shelf because the hydrodynamic energy on the open shelf was much higher. Therefore, sediments of this unit tend to coarser than facies 3.2. The surface sediment distribution demonstrates mainly muddy sand and sand (Duc et al., 2007). Sand fields distributed on the seabed at the depth deeper than $25 \mathrm{~m}$ in the study area mainly derive from earlymiddle Holocene sediments (Duc et al., 2007). This similar sedimentary characteristic was found on the SE Vietnam Shelf (Tjallingii et al., 2010; Dung et al., 2013 and Thanh, 2017). The thin thickness of U3 could be explained by the sediment discharge of the paleo-Red River system is inadequate to an extremely large and gentle area of the continental shelf and due to the high acceleration of sea-level rise in the transgression. The sea-level rise pushed fine sediments towards the coastline and trapped mainly in incised valleys or depressions.

The sea-level rise nearly reached its present position approximately 7.5-7.0 cal.kyr BP (Tjallingii et al., 2010; Stattegger et al., 2013). The maximum flooding surface was formed 
after the maximum landward migration of the shoreline $\sim 8$ cal.kyr BP. Delta sediments (cores CC, DT and ND-1) immediately above the maximum flooding surface were dated to about 7.5 -7.0 cal.kyr BP, which is in good agreement with the termination of the transgression. The U4 unit is observed overlying on the maximum flooding surface on the seismic profiles and showing the downlap structure (Figure 5, 8, 9, and 10). The dating age data of the core $\mathrm{HV}$ on the delta plain near the present shoreline indicates the delta sediment generally younger than 3 cal.kyr BP (Tanabe et al., 2006). The lithology of U4 could be inferred from the cores ND-1 and HV range from very fine silty sand to silty clay and to laminated muddy sand, corresponding to facies 3.2, 3.3 and 3.4 (Tanabe et al., 2006). Therefore, the age of U4 would be younger than 3 cal.kyr BP. During the stage of 3-0 cal.kyr BP, the sea level has declined $\sim 2$ $\mathrm{m}$ to the present sea level. The U4 unit is continuous from the delta plain to the sea and pinch out towards the shelf at the water depth of 25-30 m. The portion of the delta sediments (U4) under the present sea-level is called the subaqueous delta that surrounds the modern delta coast and forms a youngest geomorphological unit of the Red River delta. The boundary of U4 was drawn by using bathymetric data (bathymetry map with the scale 1 : 200000) in combining with some high resolution seismic data (Figure 12). This U4 unit is corresponding to the upper part of facies 3.2 and 3.3 and 3.4 in sediment cores ND-1, VN, NB, HV and GA (Tanabe et al., 2006).

Generally, the sequence stratigraphy model of the Red River subaqueous delta and the adjacent shelf could be demonstrated in Figure 13. The ages of the system tracts are predicted relatively in corresponding to the available drilling core data on the delta plain and the stages of the sea-level rise since LGM. The simplified conceptual model reveals five stages for forming four major surfaces (SB1, TS,
TRS, and MFS) and four major sedimentary units (U1, U2, U3 and U4) corresponding to the lowstand systems tract (LST), early transgressive systems tract (E-TST), late transgressive systems tract (L-TST) and highstand systems tract (HST).

\section{Conclusions}

Analyses of high-resolution seismic profiles collected from the subaqueous Red River Delta and the adjacent shelf in the Gulf of Tonkin leads to the following conclusions.

(i) The late Pleistocene-Holocene deposits in the study area generate a high-frequency sequence including lowstand, early transgressive, late transgressive and highstand systems tracts that correspond to a fifth-order sea-level change ( $20 \mathrm{kyr})$. Four major sedimentary units (U1, U2, U3 and U4) constitute the youngest sequence of the Quaternary deposits.

(ii) The lowstand systems tract (LST) defined as the U1 unit formed in completely fluvial sedimentary environments within the incised-valleys system bounded by the basal sequence boundary SB1 and the early transgressive surface (TS). The lowstand systems tract formed during the early slow sea-level rise 19-14.5 cal.kyr BP.

(iii) The transgressive systems tract (TST) includes the U2 and U3 units. The U2 unit formed in the tide-influenced river to estuary conditions in the stage of $\sim 14.5-9$ cal.kyr BP and is arranged into the early transgressive systems tract (E-TST). The U2 unit overlies on $\mathrm{U} 1$ and being separated by the early transgressive surface. The U3 unit includes shelf sediments deposited in the fully marine environments in 9-7 cal.kyr BP and probably has been reworked by modern hydrodynamic processes on the shelf. The U3 unit is arranged into the late transgressive systems tract (LTST) and is separated from the U2 unit by the transgressive ravinement surface (TRS).

(iv) The highstand systems tract is composed of the mud clinoform unit (U4) creating 
the subaqueous delta surrounding the present Red River delta coast. The sediment of U4 has been delivered from the Red River system and Thaibinh river system in the stage of $\sim 3-0$ cal.kyr BP. The subaqueous delta has prograded seawards overlying the transgressive units (U2 and U3) and being separated by the maximum flooding surface (MFS).

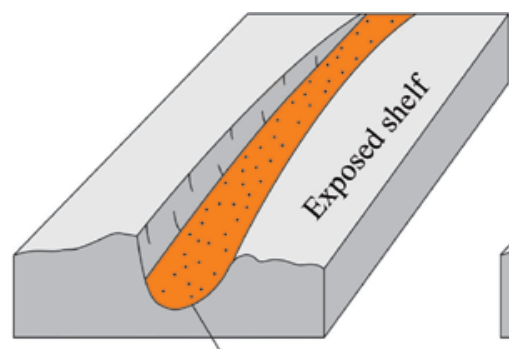

SB1

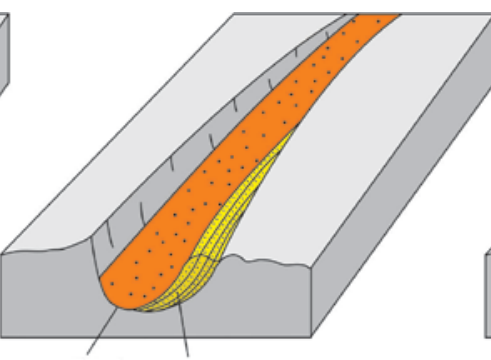

SB1 LST

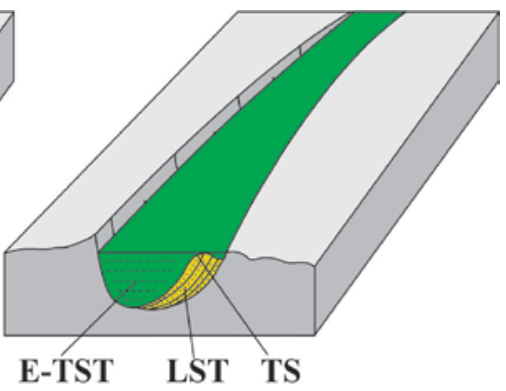

B) LST (19-14.5 cal.kyr BP)

C) E-TST (14.5-9 cal.kyr BP)

A) Sea level lowstand (23-19 cal.kyr BP)

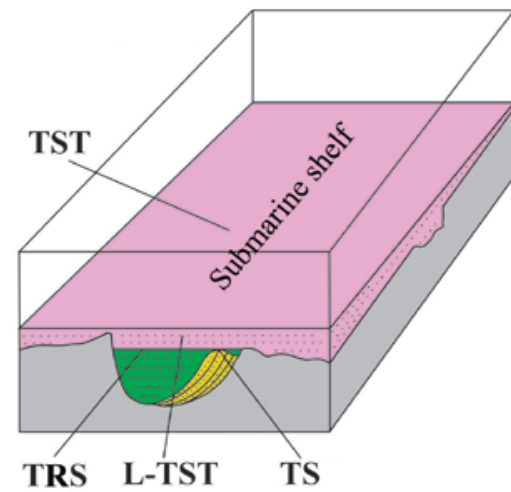

D) L-TST (9-7 cal.kyr BP)

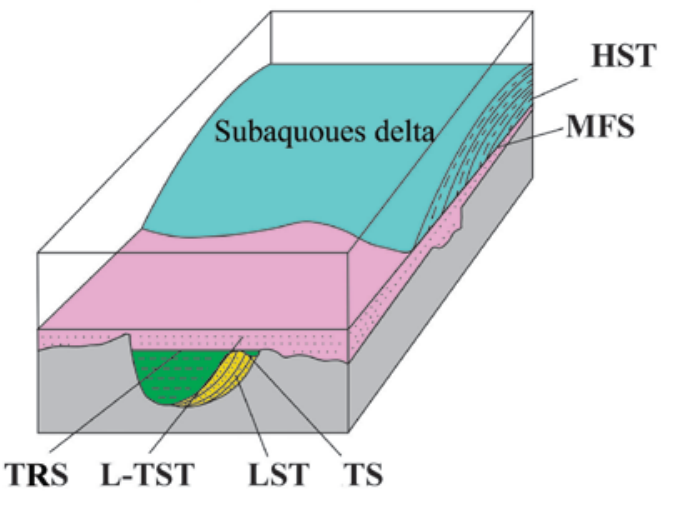

E) HST (3-0 cal.kyr BP)

\section{Legend}

\begin{tabular}{|l|l|l|l}
\hline & Valley lag deposits & Fluvial facies & $\begin{array}{l}\text { Tide-influenced river } \\
\text { to estuarine facies }\end{array}$ \\
$\square$ & Shelf facies & Subaqueous delta
\end{tabular}

Figure 13. Simplified sequence stratigraphy model showing the depositional development stages of the subaqueous Red River delta and the adjacent shelf: (A) The occurrence of sequence boundary (SB1) during the lowstand stage,

(B) Formation of LST during the early stage of slow sea-level rise, (C) Formation of E-TST, (D) Formation of

L-TST, E) Formation of HST; TS- Transgressive surface, TRS- Transgressive ravinement surface, MFS- Maximum flooding surface

\section{Acknowledgements}

The authors would like to thank the joint project between Vietnam - China "Comparative study of Holocene Sedimentary Evolution of the Yangtze River Delta and the Red River Delta", the project VAST.ĐTCB.02/16-17 and the other supports from IMGG for investigating the Red River delta.

\section{References}

Badley M.E., 1985. Practical Seismic Interpretation. International Human Resources Development Corporation, Boston, 266p. 
Nguyen Trung Thanh, et al./Vietnam Journal of Earth Sciences 40 (2018)

Bergh G.D. V.D., Van Weering T.C.E., Boels J.F., Duc D.M., Nhuan M.T., 2007. Acoustical facies analysis at the Ba Lat delta front (Red River delta, North Vietnam. Journal of Asian Earth Science, 29, 532-544.

Boyd R., Dalrymple R., Zaitlin B.A., 1992. Classification of Elastic Coastal Depositional Environments. Sedimentary Geology, 80, 139-150.

Catuneanu O., 2002. Sequence stratigraphy of clastic systems: concepts, merits, and pitfalls. Journal of African Earth Sciences, 35, 1-43.

Catuneanu O., Abreu V., Bhattacharya J.P., Blum M.D., Dalrymple R.W., Eriksson P.G., Fielding C.R., Fisher W.L., Galloway W.E., Gibling M.R., Giles K.A., Holbrook J.M., Jordan R., Kendall C.G. St. C., Macurda B., Martinsen O.J., Miall A.D., Neal J.E., Nummedal D., Pomar L., Posamentier H.W., Pratt B.R., Sarg J.F., Shanley K.W., Steel R. J., Strasser A., Tucker M.E., Winker C., 2009. Towards the standardization of sequence stratigraphy. EarthScience Reviews, 92, 1-33.

Catuneanu O., Galloway W.E., Kendall C.G. St C., Miall A.D., Posamentier H.W., Strasser A. and Tucker M.. E., 2011. Sequence Stratigraphy: Methodology and Nomenclature. Newsletters on Stratigraphy, 44(3), 173-245.

Catuneanu O., 2006. Principles of Sequence Stratigraphy. Elsevier, Amsterdam, 375p.

Coleman J.M. and Wright L.D., 1975. Modern river deltas: variability of processes and sand bodies. In: Broussard M.L (Ed), Deltas: Models for exploration. Houston Geological Society, Houston, 99-149.

Duc D.M., Nhuan M.T., Ngoi C.V., Nghi T., Tien D.M., Weering J.C.E., Bergh G.D., 2007. Sediment distribution and transport at the nearshore zone of the Red River delta, Northern Vietnam. Journal of Asian Earth Sciences, 29, 558-565.

Dung B.V., Stattegger K., Unverricht D., Phach P.V., Thanh N.T., 2013. Late Pleistocene-Holocene seismic stratigraphy of the Southeast Vietnam Shelf. Global and Planetary Change, 110, 156-169.

Embry A.F and Johannessen E.P., 1992. T-R sequence stratigraphy, facies analysis and reservoir distribution in the uppermost Triassic-Lower Jurassic succession, western Sverdrup Basin, Arctic Canada. In: Vorren T.O., Bergsager E., Dahl-Stamnes O.A., Holter E., Johansen B., Lie E., Lund T.B. (Eds.), Arctic Geology and Petroleum Potential. Special Publication. Norwegian Petroleum Society (NPF), 2, 121-146.
Funabiki A., Haruyama S., Quy N.V., Hai P.V., Thai D.H., 2007. Holocene delta plain development in the Song Hong (Red River) delta, Vietnam. Journal of Asian Earth Sciences, 30, 518-529.

General Department of Land Administration., 1996. Vietnam National Atlas. General Department of Land Administration, Hanoi, 163p.

Hanebuth T.J.J. and Stattegger K., 2004. Depositional sequences on a late Pleistocene-Holocene tropical siliciclastic shelf (Sunda shelf, Southeast Asia). Journal of Asian Earth Sciences, 23, 113-126.

Hanebuth T.J.J., Voris H.K.., Yokoyama Y., Saito Y., Okuno J., 2011. Formation and fate of sedimentary depocenteres on Southeast Asia's Sunda Shelf over the past sea-level cycle and biogeographic implications. Eath-Science Reviews, 104, 92-110.

Hanebuth T., Stattegger K. and Grootes P.M., 2000. Rapid flooding of the Sunda Shelf: a late-glacial sealevel record. Science, 288, 1033-1035.

Helland-Hansen W. and Gjelberg, J.G., 1994. Conceptual basis and variability in sequence stratigraphy: a different perspective. Sedimentary Geology, 92, 31-52.

Hori K., Tanabe S., Saito Y., Haruyama S., Nguyen V., Kitamura., 2004. Delta initiation and Holocene sealevel change: example from the Song Hong (Red River) delta, Vietnam. Sedimentary Geology, 164, 237-249.

Hunt D. and Tucker M.E., 1992. Stranded parasequences and the forced regressive wedge systems tract: deposition during base-level fall. Sedimentology Geology, 81, 1-9.

Hunt D. and Tucker M.E., 1995. Stranded parasequences and the forced regressive wedge systems tract: deposition during base-level fall-reply. Sedimentary Geology 95, 147-160.

Lam D.D. and Boyd W.E., 2000. Holocene coastal stratigraphy and model for the sedimentary development of the Hai Phong area in the Red River delta, north Viet Nam. Journal of Geology (Series B), 15-16, 18-28.

Doan Dinh Lam, 2003. History of Holocene sedimentary evolution of the Red River delta. PhD thesis in Vietnam, 129p (in Vietnamese).

Lieu N.T.H., 2006. Holocene evolution of the Central Red River delta, Northern Vietnam. PhD thesis of lithological and mineralogical in Germany, 130p.

Luu T.N.M., Garnier J., Billen G., Orange D., Némery J., Le T.P.Q., Tran H.T., Le L.A., 2010. Hydrological regime and water budget of the Red River Delta (Northern Vietnam). Journal of Asian Earth Sciences, 37, 219-228. 
Mather S.J., Davies J., Mc Donal A., Zalasiewicz J.A., and Marsh S., 1996. The Red River Delta of Vietnam. British Geological Survey Tecchnical Report WC/96/02, 41p.

Mathers S.J. and Zalasiewicz J.A.,1999. Holocene sedimentary architecture of the Red River delta, Vietnam. Journal of Coastal Research, 15, 314-325.

Milliman J.D. and Syvitski J.P.M., 1992. Geomorphic/tectonic control of sediment discharge to the Ocean: the importance of small mountainous rivers. Journal of Geology, 100, 525-544.

Milliman J.D. and Mead R.H., 1983. World-wide delivery of river sediment to the oceans. Journal of Geology, 91, 1-21.

Mitchum Jr., R.M., Vail P.R., 1977. Seismic stratigraphy and global changes of sea-level. Part 7: stratigraphic interpretation of seismic reflection patterns in depositional sequences. In: Payton C.E. (Ed.), Seismic Stratigraphy-Applications to Hydrocarbon Exploration, A.A.P.G. Memoir, 26, 135-144.

Nguyen T.T., 2017. Late Pleistocene-Holocene sedimentary evolution of the South East Vietnam Shelf, PhD thesis (in Vietnamese), Hanoi University of Science, Vietnam, 169p.

Nummedal D., Riley G.W., Templet P.T., 1993. High resolution sequence architecture: a chronostratigraphic model based on equilibrium profile studies. In: Posamentier H.W., Summerhayes C.P., Haq B.U., Allen G.P. (Eds.), Sequence stratigraphy and Facies Associations. International Association of Sedimentologists Special Publication, 18, 55-58.

Posamentier H.W. and Allen G.P., 1999. Siliciclastic sequence stratigraphy: concepts and applications. SEPM Concepts in Sedimentology and Paleontology, 7, 210p.

Posamentier H.W., Jervey M.T. and Vail P.R., 1988. Eustatic controls on clastic deposition I-Conceptual framework. Sea-level changes-An Integrated Approach, The Society of Economic Paleotologists and Minaralogist. SEPM Special Publication, 42, 109-124.

Reineck H.E., Singh I.B., 1980. Depositional sedimentary environments with reference to terrigenous clastics. Springer-Verlag Berlin Heidelberg New York, 551p.

Ross K., 2011. Fate of Red River Sediment in the Gulf of Tonkin, Vietnam. Master Thesis. North Carolina State University, 91p.

Saito Y., Katayama H., Ikehara K., Kato Y., Matsumoto E., Oguri K., Oda M., Yumoto M., 1998. Transgres- sive and highstand systems tracts and post-glacial transgression, the East China Sea. Sedimentary Geology, 122, 217-232.

Stattegger K., Tjallingii R., Saito Y., Michelli M., Nguyen T.T.., Wetzel A., 2013. Mid to late Holocene sea-level reconstruction of Southeast Vietnam using beachrock and beach-ridge deposits. Global and Planetary Change, 110, 214-222.

Tanabe S., Hori K., Saito Y., Haruyama S., Doanh L. Q., Sato Y., Hiraide S., 2003a. Sedimentary facies and radiocarbon dates of the Nam Dinh-1 core from the Song Hong (Red River) delta, Vietnam. Journal of Asian Earth Sciences, 21, 503-513.

Tanabe S., Hori K., Saito Y., Haruyama S., Phai V.V., Kitamura A., 2003b. Song Hong (Red River) delta evolution related to millennium-scale Holocene sealevel changes. Quaternary Science Reviews, 22(2122), 2345-2361.

Tanabe S., Saito Y., Lan V.Q., Hanebuth T.J.J., Lan N.Q., Kitamura A., 2006. Holocene evolution of the Song Hong (Red River) delta system, northern Vietnam. Sedimentary Geology, 187, 29-61.

Tjallingii R., Stattegger K., Wetzel A., Phung Van Phach, 2010. Infilling and flooding of the Mekong River incised valley during deglacial sea-level rise. Quaternary Science Reviews, 29, 1432-1444.

Thanh T.D. and Huy D.V., 2000. Coastal development of the modern Red River Delta. Bulletin of the Geological Survey of Japan, 5, 276.

Vail P.R., 1987. Seismic stratigraphy interpretation procedure. In: Bally, A.W. (Ed), Atlats of Seismic Stratigraphy. American Association of Petroleum Geologist Studies in Geology, 27, 1-10.

Van Wagoner J.C., Posamentier H.W., Mitchum R.M., Vail P.R., Sarg P.R., Louit J.F., Hardenbol J., 1988. An overview of the fundamental of sequence stratigraphy and key definitions. An Integrated Approach, SEPM Special Publication, 42, 39-45.

Veeken P.C.H., 2006. Seismic stratigraphy Basin Analysis and Reservoi Charactization. Handbook of geophysical exploration, Elsevier, Oxford, 37509p.

Yoo D.G., Kim S.P., Chang T.S., Kong G.S., Kang N.K., Kwon Y.K., Nam S.L., Park S.C., 2014. Late Quaternary inner shelf deposits in response to late Pleistocene-Holocene sea-level changes: Nakdong River, SE Korea. Quaternary International, 344, 156-169. 